\title{
COVID-19 - naujas iššūkis medicinos bendruomenei
}

\author{
D. Valančius* \\ V. Kasiulevičius** \\ *Vilniaus universitetas, \\ Medicinos fakultetas; \\ Vilniaus universitetas, \\ Neurologijos centras \\ **Vilniaus universitetas, \\ Medicinos fakultetas
}

\begin{abstract}
Santrauka. Koronavirusai yra svarbūs žmogaus ir gyvūnų patogenai. 2019 m. pabaigoje buvo nustatyta, kad naujas koronavirusas yra pneumonijos atvejų grupės Uhano mieste, Kinijos Hubẻjaus provincijoje priežastis. Infekcija sparčiai plinta, todėl epidemija apėmė ne tik visą Kiniją, bet vis daugiau atvejų nustatoma ir kitose šalyse visame pasaulyje. Virusas, kuris sukelia COVID-19, yra vadinamas sunkaus ūminio respiracinio sindromo koronavirusu 2 (SŪRS-CoV-2). Supratimas apie COVID-19 nuolat kinta. Šiame straipsnyje bus aptarta COVID-19 ir kitų virusų virologija, epidemiologija, klinikiniai požymiai, diagnozė ir prevencija.
\end{abstract}

Raktažodžiai: koronavirusai, SŪRS-CoV-2, COVID-19.
2019 m. gruodžio mėnesị buvo pastebėtas nežinomos kilmės pneumonijos protrūkis Uhane, Hubejjaus provincijoje, Kinijoje. Surinkus išsamią pacientų epidemiologinę anamnezę, nustatyta, kad 27 iš 41 paciento lankèsi ar dirbo didmeniniame Huanano jūros gèrybių turguje. Klinikinis pneumonijos pasireiškimas buvo būdingas virusinei pneumonijai - sausas kosulys, karščiavimas, krūtinės ląstos rentgenogramoje matoma subtili, abipusė, simetriška infiltracija. Atlikus bronchoalveolinị lavažą, išskirtas naujas koronavirusas, kurị Tarptautinis virusų taksonomijos komitetas pavadino SŪRS-CoV-2 (angl. SARS-CoV-2) arba sunkų ūmų respiracinị sindromą sukeliančiu virusu 2, o Pasaulio sveikatos organizacija (toliau - PSO) ligą pavadino COVID-19, kadangi CO - korona (angl. corona), VI viruso (angl. virus), D - liga (angl. disease) [1,2]. Viruso pavadinime yra skaičius 2 , nes šis virusas yra atitinkamai 79,0 ir 51,8 \% genetiškai tapatus su kitais dviem panašu sindromą sukeliančiais epideminiais virusais: sunkų ūmų respiracinị sindromą sukeliančiu koronavirusu (arba SŪRS-CoV), kurio protrūkis įvyko 2002 m., ir Artimujų Rytų respiracinio sindromo koronavirusu (ARRS-CoV, angl. MERS-CoV), kurio protrūkis ịvyko $2012 \mathrm{~m}$. [3, 4]. Koronavirusai yra svarbūs žmogaus ir gyvūnų patogenai RNR virusai, kuriuos galima suskirstyti į 4 gentis: alfa, be-

\author{
Adresas: \\ Domantas Valančius \\ Vilniaus universiteto Medicinos fakultetas \\ M. K. Čiurlionio g. 21, LT-03101 Vilnius \\ El.paštas domantas.valancius@santa.lt
}

ta, delta ir gama, iš kurių tik alfa ir beta koronavirusais užsikrečia žmonès. Visame pasaulyje yra keturi $\mathrm{HCoV}$ (HCoV-229E, HCoV-NL63, HCoV-OC43 ir HCoV-HKU1) endeminiai virusai, sukeliantys nuo $10 \%$ iki trečdalio bendruomenejje igytų viršutinių kvẻpavimo takų infekcijų suaugusiesiems ir vaikams. Alfakoronavirusas HCoV-229E buvo atrastas ir išskirtas iš žmogaus kvėpavimo takų 1966 m., betakoronavirusai HCoV-OC43 - 1967 m. ir SŪRS-CoV-1 - 2003 m., o alfakoronavirusas HCoV-NL63 - 2004 m., likę betakoronavirusai HCoV-HKU1 - 2005 m., MERS-CoV - 2012 m. ir SŪRS-CoV-2 - 2019 m. Yra duomenų, kad kai kurie koronavirusai sukelia viduriavimą kūdikiams ir vaikams. Vidutinių platumų klimato juostose koronavirusų sukeltos kvėpavimo takų infekcijos dažniausiai pasireiškia žiemą, nors kartais rudenị ar pavasarị pastebimi susirgimų pikai, o šios infekcijos gali pasireikšti bet kuriuo metų laiku [5-7].

\section{HCOV-OC43, HCOV-NL63, HCOV-229E IR HCOV-HKU1}

Vaikų, hospitalizuotų į Guangdžou ligonines (Kinija), septynerių metų trukmès tyrime aprašytas sezoniškumas šiame subtropiniame regione. Nors protrūkiai pasireiškẻ bet kuriuo metų laiku, tačiau daugiausia jų būta pavasarị ir rudenị [8]. Kituose tyrimuose HCoV-OC43, HCoV-NL63, HCoV-229E ir HCoV-HKU1 nenuspejamai dominuoja tam tikrais metais ir tam tikrose pasaulio dalyse [6-9]. Beveik visuose tokiuose tyrimuose $\mathrm{HCoV}-\mathrm{OC} 43$ yra labiau-

(C) Neurologijos seminarai, 2020. Open Access. This article is distributed under the terms of the Creative Commons Attribution 4.0 International License CC-BY 4.0 (http://creativecommons.org/licenses/by/4.0/), which permits unrestricted use, distribution, and reproduction in any medium, provided you give appropriate credit to the original author(s) and the source, provide a link to the Creative Commons license, and indicate if changes were made. 
siai paplitęs iš keturių žinomų padermių. Antrasis pagal paplitimą yra HCoV-NL63. Škotijoje buvo atliktas didelis polimerazės grandininès reakcijos (PGR) diagnostika pagrịstas vaikų ir suaugusiųjų, sergančių ūmine kvẻpavimo takų liga, tyrimas. Devynerius metus buvo imami daugiau kaip 44000 ligos epizodų diagnostiniai mèginiai, kurie suteikè tam tikrą supratimą apie bendruomenès įgytų $\mathrm{HCoV}$ infekcijų paplitimą ir sezoniškumą, palyginti su kitais kvèpavimo virusais vidutinių platumų klimato sąlygomis [10]. HCoV infekcijos dažniausiai pasireiškia žiemą ir yra pasiskirsčiusios visose amžiaus grupèse, tačiau aptinkamos rečiau nei rinovirusų, gripo ar kvẻpavimo takų sincitinio viruso sukeltos infekcijos. Visgi $\mathrm{HCoV}$ infekcijos paplitimas tarp mažų vaikų yra gana dažnas. Sør-Trøndelag apskrities ligoninejje (Norvegija), kuri teikia pagalbą 59000 vaikų, atliktas devynerių metų trukmės jaunesnių nei 16 metų vaikų tyrimas, kuris nustatè, kad HCoV-OC43 ir HCoV-NL63 padermès buvo dažniausiai aptinkamos kas antrą žiemą, HCoV-HKU-1 vyravo tais metais, kai HCoV-OC43 ir HCoV-NL63 nepasireikšdavo, o $\mathrm{HCoV}-229 \mathrm{E}$ paplitimas buvo nenuspèjamas [11]. Su $\mathrm{HCoV}$ susijęs hospitalizacijos dažnis dẻl apatinių kvėpavimo takų infekcijų jaunesniems nei penkerių metų vaikams buvo 1,5 iš 1000 vaikų per metus. Manoma, kad kvèpavimo takų koronavirusai plinta panašiai kaip rinovirusai, per tiesioginị sąlytị su užkrètusių asmenų išskyromis ar dideliais aerozolių lašeliais. Imunitetas vystosi netrukus po infekcijos ir, laikui bėgant, palaipsniui nyksta. Pakartotinis užsikrètimas yra dažnas, tikètina, dèl mažějančio imuniteto, tačiau gali būti ir dèl skirtingų viruso rūšių antigeninių savybių [12]. Buvo nustatyta užsikrètimo koronavirusais atvejų vaikų ligoninėse [13]. Šios infekcijos protrūkiai taip pat yra paplitę vyresnio amžiaus suaugusiụjų ilgalaikẻs priežiūros ịstaigose [14]. Nors žmogaus koronavirusai $(\mathrm{HCoV})$ jau keletą XX a. dešimtmečiu laikomi ịprastais „peršalimo“ ligas sukeliančiais patogenais, tačiau XXI a. iš gyvūnų rezervuarų atsirado ir èmẻ plisti žmonių populiacijoje 2 labai patogeniški koronavirusai: $\mathrm{HCoV}$ - sunkų umminị respiracinị sindromą sukeliantis koronavirusas (SŪRS-CoV) ir Artimujų Rytų respiracinį sindromą sukeliantis koronavirusas (MERS-CoV).

\section{SŪRS-COV}

$2002 \mathrm{~m}$. Guangdongo provincijoje (Kinija) buvo aprašyti sunkios netipinès pneumonijos atvejai. Visame pasaulyje kilo susirūpinimas dèl ligos išplitimo per tarptautines keliones ị daugiau nei dvi dešimtis šalių [15]. Nauja liga tapo žinoma kaip sunkus ūminis respiracinis sindromas (SŪRS), o sukèlejjas beta-HCoV pavadintas SŪRS-CoV. Kadangi ankstyvieji atvejai buvo susiję su žmonių ir gyvūnų sąlyčiu gyvūnų turguose, buvo ịtartas viruso perdavimas iš gyvūno žmogui [16]. Civetos (laukinès katès) ir usūriniai šunys iš pradžių buvo laikomi gyvūnų rezervuaru (-ais); tačiau, kai tapo prieinama daugiau virusinès sekos duomenų, paaiškèjo, kad natūralūs viruso šeimininkai yra šikšnosparniai. Dažni SŪRS simptomai buvo karščiavimas, kosulys, dusulys ir kartais vandeningas viduriavimas [15]. Nuo 20 iki $30 \%$ susirgusių pacientų prireiké mechaninès ventiliacijos ir net $10 \%$ jų mirè. Didesnis mirtingumas nustatytas vyresnio amžiaus pacientams ir tiems, kurie sirgo gretutinèmis ligomis. Žmogaus perdavimas žmogui buvo dokumentuotas daugiausia sveikatos priežiūros įstaigose. Žmonių bendruomenėse buvo fiksuota keletas viruso protrūkių, pavyzdžiui, viešbutyje „Metropole“ Honkonge, iš kur užsikrètę asmenys keliavo ir paskleidè SŪRS tarptautiniu mastu. Kitas Honkonge aprašytas protrūkis įvyko „Amoy Gardens“ būsto komplekse, kur užsikrètė daugiau nei 300 gyventojų. Šis atvejis įrodè, kad SŪRS-CoV plinta per orą lašeliniu būdu [17]. Nors 8098 asmenys užsikrètė ir 774 mirè, klasikinès visuomenès sveikatos priemonės sustabdè SŪRS pandemiją. Pandemija kainavo pasaulio ekonomikai nuo $30 \mathrm{iki}$ 100 milijardų dolerių. SŪRS istorija parodè, kad gyvūnų koronavirusai gali peršokti rūšių barjerą ir taip išplèsti pandemijos grèsmių sąrašą. Viruso nozokomialinio plitimo ypatumai gali būti paaiškinti tuo, kad viruso baltymas glikoproteinas $S$ jungiasi su žmogaus angiotenziną konvertuojančio fermento 2 (ACE2) receptoriais, kurie yra išsidèstę apatiniuose, o ne viršutiniuose kvėpavimo takuose. Beveik 20 metų veiksniai, susiję su SŪRS-CoV perdavimu nuo gyvūnų žmogui iki ịvykių, kai vienas žmogus užkrečia daug žmonių (angl. Superspreader), išlieka neaiškūs.

\section{MERS-COV}

2012 m. kitas labai patogeniškas beta koronavirusas taip pat peršoko rūšinį barjerą. Manoma, kad ARRS-CoV pradžioje buvo perduotas iš šikšnosparnių kupranugariams, o iš jų - žmogui. Artimujjų Rytų respiracinis sindromas (MERS) ir ARRS-CoV buvo identifikuotas Saudo Arabijoje paciento, kuris mirè nuo kvėpavimo nepakankamumo, skrepliuose [16]. Skirtingai nuo SŪRS-CoV, kuris, nors ir greitai išplito visame pasaulyje, tačiau buvo įveiktas per gana trumpą laiką, ARRS-CoV būdingi atsitiktiniai perdavimo atvejai ir ribotas plitimas tarp žmonių. ARRS-CoV užsikrètė 2494 asmenys, iš jų 858 mirè. Dauguma susirgimų fiksuota Saudo Arabijoje. PSO 2019 m. lapkričio mènesị paskelbė, kad natūralus ARRS-CoV rezervuaras yra šikšnosparniai, tačiau žmonių užsikrètimai yra priskiriami tarpiniam šeimininkui - kupranugariui. ARRS turi daug klinikinių SARS ypatybių, tokių kaip sunki atipiné pneumonija, tačiau pagrindiniai skirtumai yra akivaizdūs. ARRS sergantiems pacientams būdingi ryškūs virškinimo trakto simptomai ir dažnai - ūmus inkstų nepakankamumas, kuri greičiausiai galima paaiškinti viruso $\mathrm{S}$ glikoproteino prisijungimu prie dipeptidilpeptidazės 4 (DPP4), esančios apatiniuose kvẻpavimo takuose, virškinimo trakte ir inkstuose. Sergant ARRS, mechaninè ventiliacija reikalinga 50-89\% pacientų, o mirštamumas nuo jos yra apie $36 \%[16,17]$. 


\section{SŪRS-COV-2}

2019 m. pabaigoje buvo nustatyta, kad naujasis koronavirusas yra atipinės pneumonijos atvejų priežastis Uhane, Kinijos Hubėjaus provincijoje. Jis sparčiai plito, todèl epidemija išplito ne tik Kinijoje, bet ir visame pasaulyje. 2020 m. vasarị PSO susirgimą pavadino COVID-19, kuris reiškia 2019 m. koronaviruso ligą [18]. Virusas, kuris sukelia COVID-19, vadinamas sunkaus üminio respiracinio sindromo koronavirusu 2 (SŪRS-CoV-2); anksčiau buvo vadinamas 2019-nCoV. SÜRS-CoV-2 perduodamas asmeniui artimų kontaktų metu per orą lašeliniu būdu, kai infekuotas asmuo kosti ar čiaudi. Taip pat šiuo virusu galima užsikrèsti nuo įvairių paviršių, kadangi jis išlieka stabilus vidutiniškai 6,8 valandos ant plastiko, 5,6 valandos - ant nerūdijančio plieno, 3,5 valandos - ant kartono, 1,1 valandos - aerozolių pavidalu, 0,8 valandos - ant vario paviršiu [19].

Nors SŪRS-CoV-2 genetiškai panašus i ankstesnes epidemijas sukèlusius koronavirusus, jo genetinè struktūra labiausiai primena šikšnosparnių virusų struktūrą. Kaip jau pastebejome anksčiau, šikšnosparniai yra didžiulis įvairiausių koronavirusų rezervuaras [6]. Ištyrus skirtingų šikšnosparnių koronavirusų genomą, BatCoV RaTg13 buvo labiausiai panašus į SŪRS-CoV-2. Tarp šių virusų nustatytas net 96,3\% tapatumas [2]. Visgi lieka neaišku, kaip virusas pateko ị žmogaus organizmą: tiesiogiai iš šikšnosparnio ar perduodant dalyvavo kitas gyvūnas tarpininkas. Svarstoma, kad tai galètų būti Malaizijos pangolinas, kadangi pangolino koronavirusai filogeniškai labai panašūs i SŪRS-CoV-2. Tačiau duomenų, kaip SŪRS-CoV-2 perėjo iš pangolino žmogui, trūksta. Atlikus 103 SŪRS-CoV-2 genomo grandinių struktūros analizę, išskirti du skirtingi SŪRS-CoV-2 tipai. $70 \%$ infekcijų atitiko „L“ tipą, $30 \%$ - „S“ tipą. Manoma, kad „S“ nulemia lengvesnę, mažiau agresyvią COVID-19 eigą. "L“ tipo SŪRS-CoV-2 sąlygotas COVID-19 turèjo sunkesnę eigą [20]. Tai kontraversiška, kadangi genominis skirtumas yra vietoje, kur nekoduojami patogenezei esminiai baltymai. Spèjama, kad „S“ tipo SŪRS-CoV-2 virusas yra zoonotinis, t. y. kilęs iš gyvūno tarpininko, o „L“ tipas evoliucionavo iš „S“ tipo jau žmonių populiacijoje [21]. Skirtingas „S“ ir „L“ tipų paplitimas šalyse gali būti vienas iš faktorių, kodèl skiriasi mirtingumas tarp ịvairių šalių populiacijų. Visi koronavirusai turi teigiamo jautrumo vienagrandę RNR, kuri kartu su apsauginiu baltyminiu dangalu - nukleokapside - sudaro virioną. Koronaviruso virionai yra apgaubti lipidiniu sluoksniu. Šą lipidinę membraną virionas paima iš ląstelès šeimininkès, kurioje susidarè. Ant viruso paviršiaus yra $\mathrm{M}$ ir $\mathrm{E}$ baltymai, svarbūs šio lipidinio sluoksnio formavimui ir jo struktūros palaikymui. Tačiau patofiziologiškai esminis yra smaigalio formos baltymas. Šie baltymai išsidèstę ant viruso paviršiaus ir sudaro viruso „karūną“ (lot. corona), kuri gali būti matoma nufotografavus elektroniniu mikroskopu. Dèl smaigalio formos baltymų virusas sẻkmingai patenka ị šeimininko ląstelę [22]. Genetiškai $75 \%$ tapatų ir funkcijomis panašų baltymą turèjo ir SŪRS-CoV. Abu virusai naudoja ši baltymą prisi- jungdami prie angiotenziną konvertuojančio fermento 2 (AKF-2), tačiau SŪRS-CoV-2 smaigalio formos baltymas prisijungia stipriau $[2,19]$. Dar didesnis genetinis atitikimas yra tarp SŪRS-CoV-2 ir pangolinų bei šikšnosparnių smaigalio formos baltymų - jų amino rūgščių išsidèstymas sutampa daugiau nei $90 \%$. Tai vienas iš pagrindinių argumentų, kad SŪRS-CoV-2 kilo iš šių gyvūnų koronavirusų [23]. Koronavirusų smaigalio formos baltymas iš šeimininko ląstelès pasisavina angliavandenius, dèl to tampa stipriai glikozilintas ir apsisaugo nuo žmogaus imuninès sistemos [24]. Manoma, kad, norint sukurti efektyvų vaistą ar vakciną, smaigalio formos baltymas bus esminis baltymas-taikinys.

\section{Patogenezè}

COVID-19 patogenezė iš esmės nežinoma, tačiau ankstyvieji tyrimai rodo, kad SŪRS-CoV-2 glikoproteinai (S baltymai) jungiasi su angiotenziną konvertuojančio fermento 2 (ACE2) receptoriais, esančiais kvẻpavimo taku epitelinių ląstelių membranose ir širdies audinyje, taip pat monocituose ir makrofaguose. Limfopenija yra susijusi su sunkia ligos eiga. T ląstelių apoptozė ir išsekimas gali prisidèti prie imunopatologijos. Manoma, kad citokinų audra, kaip ir MERS-CoV ir SŪRS-CoV-1 atvejais, vaidina svarbų vaidmenị šios infekcijos eigoje. Padidejęs interleukino-6 (IL-6) kiekis yra susijęs su ARDS ir kvėpavimo nepakankamumu pacientams, sergantiems COVID-19 [25-27]. Tačiau, daugèjant duomenų, jau galima susidaryti loginę ligos patogenezès grandinę. SŪRS-CoV-2, naudodamasis smaigalio formos baltymu, prisijungia prie AKF-2 ir patenka ị II tipo pneumocitus, kurie randasi apatiniuose kvèpavimo takuose alveolèse. SŪRS-CoV-2 į ląstelę-taikinị gali patekti dviem būdais: efektyvesniu ir endocitozès būdu. Tačiau tam, kad virusas patektų efektyvesniu būdu, reikalingas kitas II tipo pneumocito paviršiuje esantis baltymas - transmembraninis serino proteazès baltymas 2 (TMSPB-2). Virusas prisijungia prie AKF2 bei TMSPB2 ir taip susijungia su pažeidžiamos ląstelès membrana. Tokiu būdu labai efektyviai išleidžia viriono sudėtị - RNR i ląstelę. Kai TMSPB-2 nenaudojamas, virusas patenka ị ląstelę endocitozès būdu. Endocitozė yra procesas, kai išorinis darinys (šiuo atveju koronavirusas) apgaubiamas fosfolipidine membrana ir patenka ị ląstelès vidų. Po to viruso RNR yra išskiriama iš fosfolipidinio dangalo [28]. Vienaip ar kitaip, jau laisva viruso RNR susijungia su šeimininko ribosomomis ir transliuojama i polipeptidus. Pasitelkiant šeimininko ląstelès proteazes, iš susidariusių polipeptidų konstruojami viriono struktūriniai ir membraniniai baltymai. Transliacijos metu taip pat pagaminama nuo RNR priklausoma RNR polimerazé, kuri duplikuoja viruso RNR grandinę. Ši kartu su jau suformuotais baltymų subvienetais patenka į Golgi aparatą ląsteleje, kur besiformuojantis virionas bus apgaubiamas lipidine membrana ir galès būti išskirtas iš ląstelès egzocitozès būdu, kaip funkcionuojantis virusas. Tuo pačiu metu, kai vyksta viruso replikacija, pažeisti II tipo pneumocitai išskiria signalines molekules - citokinus: alfa ir beta inter- 
feronus. Interferonai signalizuoja netoliese esančioms ląstelèms, kad virusas jau yra alveoleje, todèl pradedami gaminti antivirusiniai baltymai. Kartu su interferono gamyba pažeisti II tipo pneumocitai išskiria su pažeidimu susijusias molekulines struktūras (angl. damage associated molecular patterns). Išskirtos molekulès sužadina alveolèje esančius makrofagus, kurie „aktyvuojasi“ ir išskiria didžiuli kieki uždegiminių mediatorių: IL-1, IL-6, IL-8, TNF-alfa, gama interferonus ir kitus chemokinus. Garsioji „citokinų audra“ yra būtent šio proceso padarinys [26]. Uždegiminis procesas dirgina alveoles įnervuojančių nervų galūnèles, taip sužadindamas kosėjimo refleksą ir bronchospazmą. Dèl šios priežasties neretai pirmasis simptomas, susirgus COVID-19, yra sausas kosulys. Uždegiminiams citokinams patekus ị kapiliarus, sužadinamos endotelinės ląstelès, kurios pradeda judèti viena arčiau kitos, dèl to plaučių alveoles supančiuose kapiliaruose susidaro tarpai. Iš kapiliarinio indo per atsidariusius tarpus ị ertmę tarp alveolès ir kapiliaro - intersticiumą subėga skystis ir sukelia intersticinę edemą. Laikui bėgant, iš intersticiumo skystis patenka ir ị alveolę. Dèl šio proceso nebeįmanoma deguonies ir anglies dvideginio perfuzija per kapiliaro-alveolès sienelę, todèl nevyksta kvèpavimas. Nors deguonis gali patekti ị alveolę, jis negali patekti ị kraują. Tai vadinama ventiliacijos ir perfuzijos neatitiktimi. Negana to, skystis, patekęs ị alveolę, nuvalo alveolès paviršiuje esantị apsauginị sluoksnị - surfaktantą, dèl to alveolèje padidèja paviršiaus įtampa ir alveolè subliūkšta. Tai vadinama ūminiu respiraciniu distreso sindromu (ŪRDS), dèl kurio išsivysto I tipo (hipokseminis) kvėpavimo nepakankamumas. Tačiau nèra visiškai žinoma, kaip konkrečiai SŪRS-CoV-2 atveju šis sindromas išsivysto [29]. Pagal naujus duomenis, COVID-19 sukeltas ŪRDS yra kitoks, reikalaujantis kitokių gydymo metodų, nei icprastas ŪRDS [30]. Sunkesnę COVID-19 klinikinę eigą lemia ne pats virusas, bet viruso ir šeimininko ląstelių sąveika. Geresnis supratimas apie SŪRS-CoV-2 patogenezę neabejotinai duos svarbių įžvalgų gydant COVID-19. İdomu tai, kad daugiausiai AKF-2 ir TMSPB-2 fermentų yra ne plaučiuose, o virškinimo trakte [31]. Būtent AKF-2 receptorius yra didžiulių diskusijų objektas. Yra manančių, kad AKF-2 receptorių tankumas audinyje nulemia jo pažeidimą, todèl vertètų mažinti AKF-2 aktyvumą $[32,33]$. Tačiau kiti galvoja, kad, didinant AKF-2 receptorių ekspresiją, galima būtų apsaugoti ląstelę nuo viruso [34]. AKF-2 ir TMSPB-2 taip pat yra gausiai ekspresuojami ir kepenu cholangiocituose, šlapimo pūslès uretelio ląstelèse, stemplès keratinocituose, inkstų proksimalinio vingiuotojo kanalèlio ląstelèse $[35,36]$. Tačiau virusas retai pažeidžia šias ląsteles ir sukelia atitinkamo organo disfunkciją. Širdies miocituose AKF-2 receptoriai taip pat yra gausiai ekspresuojami, o širdies miocitų pažeidimas pasitaiko dažnai. Uhano klinikinèje studijoje net $12 \%$ infekuotų žmonių buvo rasta ūmi miokardo pažaida [37]. Nežinoma, ar tai susiję su tiesioginiu viruso pažeidimu, ar su viruso sukelta hiperkoaguliacija [38]. Pastebėta, kad, skirtingai nuo SŪRS-CoV, hiperkoaguliacija SŪRS-CoV-2 patogenezèje vaidina svarbų vaidmenic. SŪRS atveju trombozès buvo retas fenomenas, o COVID-19 yra būdingas aukštas D-dimerų ir fibrinogeno lygis, prailgèjęs protrombino laikas bei didžiulis trombozių ir plaučių arterijų trombembolijos dažnis, ypač tarp sergančiujų sunkia ligos forma [37, 38]. Spėjama, kad tai taip pat yra didžiulio uždegimo pasekmė: komplementas ir kiti ūmios fazès baltymai bei citokinai sukelia endotelio disfunkciją (vienas iš Virchovo triados veiksnių) [39].

\section{Inkubacinis periodas}

Manoma, kad COVID-19 inkubacinis laikotarpis yra iki 14 dienų po ekspozicijos, dažniausiai tai įvyksta maždaug per keturias-penkias dienas. 1099 pacientų, susirgusių COVID-19, tyrime vidutinis inkubacinis periodas buvo keturios paros (tarpkvartilinis intervalas - nuo dviejų iki septynių parų) [40].

\section{Klinika}

Lengvi ir vidutinio sunkumo simptomai gali atsirasti per 2-14 dienų po užsikrètimo. Dažniausi ligos simptomai yra kosulys, dusulys, pasunkèjęs kvėpavimas, kiti - karščiavimas, šaltkrètis, raumenų, galvos, gerklès skausmas, kvapo ar skonio sutrikimai. Remiantis 181 paciento duomenimis, nustatyta, kad 2,5\% užsikrètusių asmenų simptomai pasireiškẻ per 2,2 dienos, o 97,5\% užsikrètusių asmenų - per 11,5 dienos. Vidutinis inkubacinis periodas šiame tyrime buvo 5,1 dienos. Ligos sunkumo spektras svyruoja nuo lengvos iki kritinės; dauguma infekcijų nėra sunkios [25]. Kinijos ligų kontrolès ir prevencijos centro duomenys rodo, kad iš 44500 susirgusių lengvi atvejai, kai nesusergama plaučių uždegimu ar pasireiškia tik lengvos pneumonijos požymiai, buvo nustatyti $81 \%$ pacientų. Tuo tarpu sunki ligos eiga, pasireiškianti dusuliu, hipoksija ir pokyčiais abiejuose plaučiuose, sudarè 14 \% pacientų. Kritinè ligos eiga, kai vystosi kvėpavimo nepakankamumas, šokas ar daugiafunkciniai sutrikimai, buvo nustatyta $5 \%$ pacientų. Mokslinėse publikacijose yra aprašyti besimptomės infekcijos atvejai [3], tačiau jų dažnis - nežinomas. Kruiziniame laive „Diamond Princess“ COVID-19 protrūkio metu beveik visi keleiviai ir personalas buvo ištirti, ar yra užsikrètę SŪRS-CoV-2. Net $17 \%$ laive esančių keleivių patvirtintas užsikrètimas ir maždaug pusė iš 619 patvirtintų COVID-19 atvejų diagnozès nustatymo metu buvo besimptomiai [41]. Tačiau net sergantieji besimptome infekcijos forma gali turèti objektyvių klinikinių pokyčių [37, 42]. Pavyzdžiui, tyrime, kuriame dalyvavo 24 pacientai, kuriems buvo nustatyta besimptomė ligos eiga, atlikus kompiuterinę krūtinès ląstos tomografiją, net $50 \%$ jų rasta virusinei pneumonijai būdingų radiologinių pokyčių.

\section{Diagnostika}

Iki šiol dažniausiai naudojamas ir patikimiausias COVID-19 diagnozavimo tyrimas yra RT-PGR tyrimas, atliekamas tiriant nosiaryklès tepinèlius ar kitus viršuti- 
nių kvėpavimo takų mėginius. Laboratoriniai pokyčiai gali būti svarbūs identifikuojant pacientus, kuriems yra didesnė nepageidaujamų ịvykių rizika. Wang ir kt. paskelbe įdomią ataskaitą, kurioje vertinti šešių laboratorinių parametrų duomenys per 19 hospitalizacijos dienų 138 pacientams, sergantiems COVID-19 (33 iš jų pasireiškè sunki ligos eiga), iš kurių penki mirẻ ligoninėje [43]. Pastebèta keletas reikšmingų skirtumų tarp pacientų, kurie gydyti intensyviosios terapijos skyriuje, ir tų, kuriems toks gydymas nebuvo skirtas. Hospitalizuotiems i intensyviosios terapijos skyrių pacientams nustatytas didesnis leukocitu (WBC) kiekis (1,5 karto), didesnis neutrofilų skaičius (1,7 karto), mažesnis limfocitų skaičius ( 0,9 karto), taip pat didesnės LDH vertès (2,1 karto), alanino aminotransferazès (ALT) (1,5 karto), aspartato aminotransferazès (AST) (1,8 karto), bendro bilirubino (1,2 karto), kreatinino (1,1 karto), širdies troponino I (2,2 karto), D-dimero (2,5 karto) ir prokalcitonino (1,2 karto) vertès. Taip pat nustatyta, kad neišgyvenusiems žmonėms dažniau išsivystė limfopenija ir leukocitozè, taip pat nustatytos padidèjusios D-dimerų, urea ir kreatinino vertès. Radiologiniai COVID-19 pneumonijos ypatumai: nespecifinis, bet dažniausias, yra plaučių „matinio stiklo" (angl. ground glass) vaizdas; pokyčiai dažniausiai būna abiejuose plaučiuose (abipusiškumas); dažniau pakitimai periferinèse plaučių dalyse; perèjimas ị „grindinio vaizdą“ (angl. crazy-paving) - tai „matinio stiklo" zonos su tarpskiltelinių pertvarèlių sustorèjimu; „matinio stiklo“ pakitimai laike progresuoja konsolidacijos link (dažniausiai antrą ligos savaitę); limfadenopatija ir pleuritas nėra būdingi; nuo simptomų pradžios KT pakitimų dinamika greita; radiologinių pakitimų pikas KT yra 6-11 dienų nuo susirgimo pradžios; dominuojantis KT pakitimas ligos pradžioje - „matinio stiklo“ pokyčiai, o 12-17 ligos dieną jau dominuoja mišrūs pokyčiai; pacientams, sveikstantiems nuo COVID-19 pneumonijos (išskyrus sunkų respiracinį distreso sindromą ligos eigoje), 10 ligos dieną nuo simptomų pradžios yra nustatyti didžiausi pakitimai plaučių KT. Galima išskirti keturias plaučių KT pakitimų laike stadijas: ankstyva (0-4 dienos); progresijos (5-8 dienos); piko (10-13 dienų) ir absorbcijos ( $\geq 14$ dienų) [44].

\section{Gydymas}

Iki šiol nèra ịrodymais pagrịsto infekcijos gydymo. Intensyvūs tyrimai atliekami su remdesiviru, naudojamais gydant ŽIV lopinaviru ir ritonaviru, taip pat chlorokvinu ir hidroksichlorokvinu, kurie skiriami gydyti maliariją ir tam tikras autoimunines ligas, sisteminiais interferonais, ypač beta interferonu, kuris naudojamas išsėtinei sklerozei gydyti, monokloniniais antikūnais, veikiančiais imuninès sistemos komponentus, ir pasveikusiujų asmenų kraujo plazma. Kol nėra sukurta efektyvi vakcina ir atrastas tinkamas gydymas, didžiausias dėmesys skiriamas viruso plitimui stabdyti klasikinėmis visuomenès sveikatos priemonėmis: socialinès distancijos palaikymui, tinkamoms apsaugos priemonėms [45].

\section{Literatūra}

1. WHO. Novel Coronavirus (2019-nCoV) Situation Report - 22 [Internet]. February 11, 2020 [cited 2020 May 10]. Available from: https://www.who.int/docs/default-source/ coronaviruse/situation-reports/20200211-sitrep-22-ncov. pdf?sfvrsn=fb6d49b1_2

2. Zhou P, Yang X Lou, Wang XG, Hu B, Zhang L, Zhang W, et al. A pneumonia outbreak associated with a new coronavirus of probable bat origin. Nature 2020; 579(7798): 270-3. https://doi.org/10.1038/s41586-020-2012-7

3. Chan JFW, Yuan S, Kok KH, To KKW, Chu H, Yang J, et al. A familial cluster of pneumonia associated with the 2019 novel coronavirus indicating person-to-person transmission: a study of a family cluster. Lancet 2020; 395(10223): 514-23. https://doi.org/10.1016/S01406736(20)30154-9

4. Ren LL, Wang YM, Wu ZQ, Xiang ZC, Guo L, Xu T, et al. Identification of a novel coronavirus causing severe pneumonia in human: a descriptive study. Chin Med J (Engl) 2020; 133(9): 1015-24. https://doi.org/10.1097/ CM9.0000000000000722

5. Mcintosh K, Kapikian AZ, Turner HC, Hartley JW, Parrott RH, Chanock RM. Seroepidemiologic studies of coronavirus infection in adults and children. Am J Epidemiol 1970; 91(6): 585-92. https://doi.org/10.1093/ oxfordjournals.aje.a121171

6. Vabret A, Dina J, Gouarin S, Petitjean J, Tripey V, Brouard J, et al. Human (non-severe acute respiratory syndrome) coronavirus infections in hospitalised children in France. J Paediatr Child Health 2008; 44(4): 176-81. https://doi.org/ 10.1111/j.1440-1754.2007.01246.x

7. Gaunt ER, Hardie A, Claas ECJ, Simmonds P, Templeton KE. Epidemiology and clinical presentations of the four human coronaviruses 229E, HKU1, NL63, and OC43 detected over 3 years using a novel multiplex real-time PCR method. J Clin Microbiol 2010; 48(8): 2940-7. https://doi.org/10.1128/JCM.00636-10

8. Zeng ZQ, Chen DH, Tan WP, Qiu SY, Xu D, Liang HX, et al. Epidemiology and clinical characteristics of human coronaviruses OC43, 229E, NL63, and HKU1: a study of hospitalized children with acute respiratory tract infection in Guangzhou, China. Eur J Clin Microbiol Infect Dis 2018; 37(2): 363-9. https://doi.org/10.1007/s10096-017-3144-z

9. Monto AS. Coronaviruses. Yale J Biol Med 1974; 47(4): 234-51.

10. Nickbakhsh S, Thorburn F, Von Wissmann B, McMenamin J, Gunson RN, Murcia PR. Extensive multiplex PCR diagnostics reveal new insights into the epidemiology of viral respiratory infections. Epidemiol Infect 2016; 144(10): 2064-76. https://doi.org/10.1017/S0950268816000339

11. Heimdal I, Moe N, Krokstad S, Christensen A, Skanke LH, Nordbø SA, et al. Human coronavirus in hospitalized children with respiratory tract infections: a 9-year populationbased study from Norway. J Infect Dis 2019; 219(8): 1198-206. https://doi.org/10.1093/infdis/jiy646

12. Reed SE. The behaviour of recent isolates of human respiratory coronavirus in vitro and in volunteers: Evidence of heterogeneity among 229E-related strains. J Med Virol 1984; 13(2): 179-92. https://doi.org/10.1002/jmv.1890130208

13. Gagneur A, Vallet S, Talbot PJ, Legrand-Quillien MC, Picard B, Payan C, et al. Outbreaks of human coronavirus in a paediatric and neonatal intensive care unit. Eur J Pediatr 
2008; 167(12): 1427-34. https://doi.org/10.1007/s00431008-0687-0

14. Falsey AR, Dallal GE, Formica MA, Andolina GG, Hamer DH, Leka LL, et al. Long-term care facilities: a cornucopia of viral pathogens. J Am Geriatr Soc 2008; 56(7): 1281-5. https://doi.org/10.1111/j.1532-5415. 2008.01775.x

15. De Wit E, Van Doremalen N, Falzarano D, Munster VJ. SARS and MERS: recent insights into emerging coronaviruses. Nat Rev Microbiol 2016; 14(8): 523-34. https://doi.org/10.1038/nrmicro.2016.81

16. Song Z, Xu Y, Bao L, Zhang L, Yu P, Qu Y, et al. From SARS to MERS, thrusting coronaviruses into the spotlight. Viruses 2019; 11(1): 59. https://doi.org/10.3390/v11010059

17. Yu ITS, Li Y, Wong TW, Tam W, Chan AT, Lee JHW, et al. Evidence of airborne transmission of the severe acute respiratory syndrome virus. N Engl J Med 2004; 350(17): 1731-9. https://doi.org/10.1056/NEJMoa032867

18. WHO. Coronavirus disease 2019 (COVID-19) Situation Report - 51 [Internet]. March 11, 2020 [cited 2020 May 4]. Available from: https://www.who.int/docs/default-source/ coronaviruse/situation-reports/20200311-sitrep-51-covid19.pdf

19. van Doremalen N, Bushmaker T, Morris DH, Holbrook MG, Gamble A, Williamson BN, et al. Aerosol and surface stability of SARS-CoV-2 as compared with SARS-CoV-1. N Engl J Med 2020; 382(16): 1564-7. https://doi.org/10.1056/ NEJMc2004973

20. Tang X, Wu C, Li X, Song Y, Yao X, Wu X, et al. On the origin and continuing evolution of SARS-CoV-2. Natl Sci Rev 2020; nwaa036. https://doi.org/10.1093/nsr/nwaa036

21. Ji W, Wang W, Zhao X, Zai J, Li X. Cross-species transmission of the newly identified coronavirus 2019-nCoV. J Med Virol 2020; 92(4): 433-40. https://doi.org/10.1002/ jmv.25682

22. Walls AC, Park YJ, Tortorici MA, Wall A, McGuire AT, Veesler D. Structure, function, and antigenicity of the SARS-CoV-2 spike glycoprotein. Cell 2020; 181(2): 281-92. https://doi.org/10.1016/j.cell.2020.02.058

23. Pillay TS. Gene of the month: the 2019-nCoV/SARS-CoV-2 novel coronavirus spike protein. J Clin Pathol 2020; 1-4. https://doi.org/10.1136/jclinpath-2020-206658

24. Wan Y, Shang J, Graham R, Baric RS, Li F. Receptor recognition by the novel coronavirus from Wuhan: an analysis based on decade-long structural studies of SARS coronavirus. J Virol 2020; 94(7): 1-9. https://doi.org/ 10.1128/JVI.00127-20

25. Graham Carlos W, Dela Cruz CS, Cao B, Pasnick S, Jamil S. Novel Wuhan (2019-NCoV) coronavirus. Am J Respir Crit Care Med 2020; 201(4): P7-8. https://doi.org/10.1164/ rccm.2014P7

26. Moore JB, June $\mathrm{CH}$. Cytokine release syndrome in severe COVID-19. Science 2020; 368(6490): 473-4 https://doi.org/10.1126/science.abb8925

27. Wang W, Tang J, Wei F. Updated understanding of the outbreak of 2019 novel coronavirus (2019-nCoV) in Wuhan, China. J Med Virol 2020; 92(4): 441-7. https://doi.org/ 10.1002/jmv. 25689

28. Simmons G, Zmora P, Gierer S, Heurich A, Pöhlmann S. Proteolytic activation of the SARS-coronavirus spike protein: cutting enzymes at the cutting edge of antiviral research. Antiviral Research 2013; 100: 605-14. https://doi.org/ 10.1016/j.antiviral.2013.09.028
29. Thompson BT, Chambers RC, Liu KD. Acute respiratory distress syndrome. N Engl J Med 2017; 377(6): 562-72. https://doi.org/10.1056/NEJMra1608077

30. Gattinoni L, Chiumello D, Caironi P, Busana M, Romitti F, Brazzi L, et al. COVID-19 pneumonia: different respiratory treatments for different phenotypes? Intensive Care Med 2020; 6-9. https://doi.org/10.1007/s00134-020-06033-2

31. Uhlén M, Fagerberg L, Hallström BM, Lindskog C, Oksvold P, Mardinoglu A, et al. Proteomics. Tissue-based map of the human proteome. Science 2015; 347(6220): 1260419. https://doi.org/10.1126/science. 1260419

32. Xu H, Zhong L, Deng J, Peng J, Dan H, Zeng X, et al. High expression of ACE2 receptor of 2019-nCoV on the epithelial cells of oral mucosa. Int J Oral Sci 2020; 12(1): 1-5. https://doi.org/10.1038/s41368-020-0074-x

33. Zhang H, Penninger JM, Li Y, Zhong N, Slutsky AS. Angiotensin-converting enzyme 2 (ACE2) as a SARS-CoV-2 receptor: molecular mechanisms and potential therapeutic target. Intensive Care Med 2020; 46(4): 586-90. https://doi.org/10.1007/s00134-020-05985-9

34. Hamming I, Timens W, Bulthuis MLC, Lely AT, Navis GJ, van Goor $\mathrm{H}$. Tissue distribution of ACE2 protein, the functional receptor for SARS coronavirus. A first step in understanding SARS pathogenesis. J Pathol 2004; 203(2): 631-7. https://doi.org/10.1002/path.1570

35. Zou X, Chen K, Zou J, Han P, Hao J, Han Z. Single-cell RNA-seq data analysis on the receptor ACE2 expression reveals the potential risk of different human organs vulnerable to 2019-nCoV infection. Front Med 2020; 14(2): 185-92. https://doi.org/10.1007/s11684-020-0754-0

36. Qi F, Qian S, Zhang S, Zhang Z. Single cell RNA sequencing of 13 human tissues identify cell types and receptors of human coronaviruses. Biochem Biophys Res Commun 2020; 526(1): 135-40. https://doi.org/10.1016/j.bbrc.2020.03.044

37. Huang C, Wang Y, Li X, Ren L, Zhao J, Hu Y, et al. Clinical features of patients infected with 2019 novel coronavirus in Wuhan, China. Lancet 2020; 395(10223): 497-506. https://doi.org/10.1016/S0140-6736(20)30183-5

38. Zheng YY, Ma YT, Zhang JY, Xie X. COVID-19 and the cardiovascular system. Nat Rev Cardiol 2020; 17(5): 259-60. https://doi.org/10.1038/s41569-020-0360-5

39. Magro C, Mulvey JJ, Berlin D, Nuovo G, Salvatore S, Harp J, et al. Complement associated microvascular injury and thrombosis in the pathogenesis of severe COVID-19 infection: a report of five cases. Transl Res 2020; 220: 1-13. https://doi.org/10.1016/j.trsl.2020.04.007

40. Guan WJ, Ni ZY, Hu Y, Liang WH, Ou CQ, He JX, et al. Clinical characteristics of coronavirus disease 2019 in China. N Engl J Med 2020; 382(18): 1708-20. https://doi.org/ 10.1056/NEJMoa2002032

41. Japanese National Institute of Infectious Diseases. Field Briefing: Diamond Princess COVID-19 Cases, 20 Feb Update [Internet] [cited 2020 May 20]. Available from: https://www.niid.go.jp/niid/en/2019-ncov-e/9417-coviddp-fe-02.html

42. Chen N, Zhou M, Dong X, Qu J, Gong F, Han Y, et al. Epidemiological and clinical characteristics of 99 cases of 2019 novel coronavirus pneumonia in Wuhan, China: a descriptive study. Lancet 2020; 395(10223): 507-13. https://doi.org/ 10.1016/S0140-6736(20)30211-7

43. Wang D, Hu B, Hu C, Zhu F, Liu X, Zhang J, et al. Clinical characteristics of 138 hospitalized patients with 2019 novel coronavirus-infected pneumonia in Wuhan, China. JAMA 
2020; 323(11): 1061-9. https://doi.org/10.1001/jama. 2020.1585

44. Wang YM. Temporal changes of CT findings in 90 patients with COVID-19 pneumonia: a longitudinal study. Radiology 2020; 200843. https://doi.org/10.1148/radiol.2020200843

45. Jüni P, Rothenbühler M, Bobos P, Thorpe KE, da Costa BR, Fisman DN, et al. Impact of climate and public health interventions on the COVID-19 pandemic: a prospective cohort study. Can Med Assoc J 2020; 192(21): E566-73 https://doi.org/10.1503/cmaj.200920

\section{Valančius, V. Kasiulevičius}

COVID-19 - A NEW CHALLENGE FOR THE MEDICAL COMMUNITY

\section{Summary}

Coronaviruses are important human and animal pathogens. At the end of 2019, a novel coronavirus was identified as the cause of a cluster of pneumonia cases in Wuhan, a city in the Hubei Province of China. It rapidly spread resulting in an epidemic throughout China followed by an increasing number of cases in other countries throughout the world. The virus that causes COVID-19 is designated severe acute respiratory syndrome coronavirus 2 (SARS-CoV-2). Understanding of COVID-19 is evolving. This article discusses the virology, epidemiology, clinical features, diagnosis, and prevention of COVID-19 and other coronaviruses.

Keywords: coronaviruses, SARS-CoV-2, COVID-19.

Gauta:

Priimta spaudai:

20200517 